\title{
Is Every Foot Wound a Diabetic Foot Infection in Diabetic Patients? A Case of Kaposi Sarcoma
}

\section{Diyabetli Hastalarda Gelişen Her Ayak Yarası Diyabetik Ayak Enfeksiyonu Mudur? Bir Kaposi Sarkomu Olgusu}

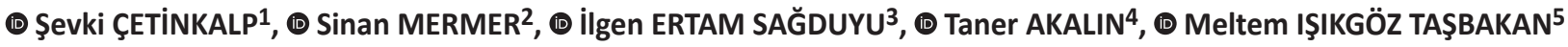 \\ ${ }^{1}$ Ege University Faculty of Medicine, Department of Internal Diseases, Division of Endocrinology, Izmir, Turkey \\ 2 Çine State Hospital, Clinic of Infectious Diseases and Clinical Microbiology, Aydın, Turkey \\ ${ }^{3}$ Ege University Faculty of Medicine, Department of Dermatology, Izmir, Turkey \\ ${ }^{4}$ Ege University Faculty of Medicine, Department of Medical Pathology, Izmir, Turkey \\ ${ }^{5}$ Ege University Faculty of Medicine, Department of Infectious Diseases and Clinical Microbiology, Izmir, Turkey
}

Keywords: Diabetes mellitus, radiotherapy, case report, chronic wound, HHV-8

Anahtar Kelimeler: Diabetes mellitus, radyoterapi, olgu sunumu, kronik yara, HHV-8

\section{Dear Editor,}

Chronic wounds have a very long and difficult healing process and their tendency to recur is high. Although they are usually associated with etiological factors such as diabetes, chronic compression, arterial stenosis or occlusion, venous insufficiency, radiation damage, and connective tissue disorders, chronic wounds can occasionally be caused by malignancies as well ${ }^{[1]}$. Herein, we share a case of Kaposi's sarcoma in a patient with type 2 diabetes who presented with a foot wound.

A 70-year-old female patient with known type 2 diabetes mellitus, hypertension, and hyperlipidemia presented to our clinic with exudative wounds on the sole of her right foot (Figure 1) that had been persisting for approximately six months. In her history the patient reported using various oral antibiotics prescribed in the other centers she had consulted. However, she did not know the antibiotic names and her wounds persisted. The patient was evaluated by the Diabetic Foot Council of the Ege University Faculty of Medicine. Physical examination revealed increased calf diameter and nonpitting edema in the right leg and sporadic yellow-purple hyperkeratotic papular lesions on a hyperemic base with seropurulent exudates on their surfaces on the sole of the right foot that were inconsistent with classical diabetic foot wound. The patient was admitted for further testing. Laboratory results were as follows: white blood

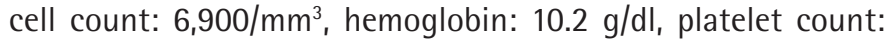
292,000/ $\mathrm{mm}^{3}$, C-reactive protein: $0.91 \mathrm{mg} / \mathrm{dl}$ (reference range: $<0.5 \mathrm{mg} / \mathrm{dl}$ ), and erythrocyte sedimentation rate: $11 \mathrm{~mm} / \mathrm{hr}$. Liver and kidney function test results were normal. Direct $\mathrm{X}$-ray did not reveal any findings suggestive of osteomyelitis while a magnetic resonance imaging was not planned. Tissue samples were taken from the lesion and the samples were sent to the Microbiology and Pathology Laboratories. Empirical amoxicillin/ clavulanic acid therapy was initiated at $1 \mathrm{~g}$ every 12 hours. Tissue culture was negative. Pathological examination of the tissue biopsy was reported to be consistent with nodular Kaposi's sarcoma. Human Herpesvirus-8, CD31, and CD34 positivity were detected on immunohistochemical examination. Human Immunodeficiency Virus, hepatitis B, hepatitis C, and VDRL (Venerial Diseases Research Laboratory Test) serology results were negative. Thoracic and abdominal computed tomography scans performed for malignancy staging did not reveal any

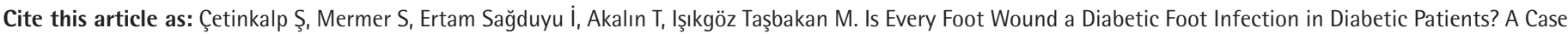
of Kaposi Sarcoma. Mediterr J Infect Microb Antimicrob. 2019;8:19. 


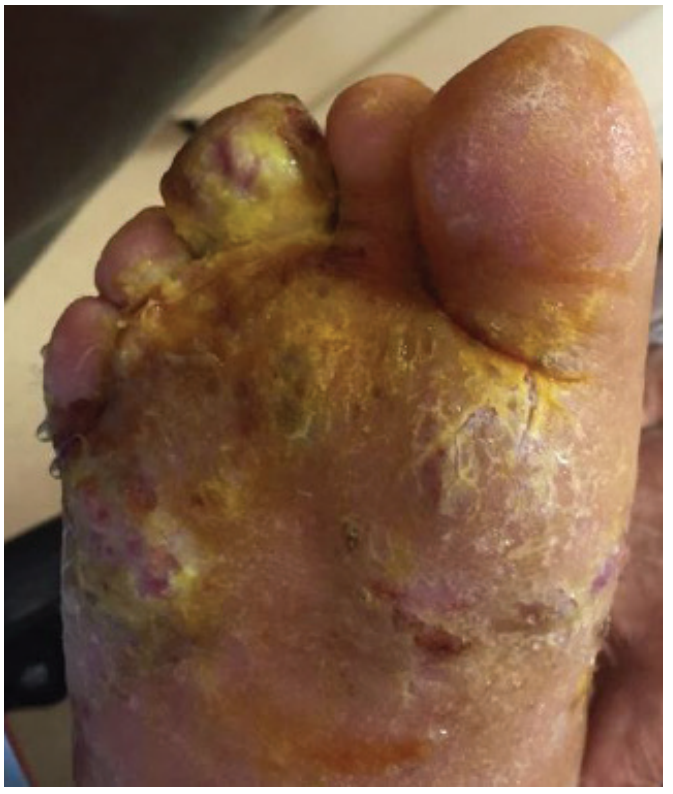

Figure 1. Kaposi's sarcoma

pathology. The patient was evaluated by the Department of Oncology based on her test results and radiotherapy was planned. She underwent a single session of radiotherapy to her right foot in the Oncology Department Radiation, after which she was transferred to the Oncology Department for maintenance therapy. The patient remains under follow-up in the Oncology and Endocrinology Outpatient Clinics.

Healing of chronic wounds is delayed due to a number of underlying problems. These wounds do not go through the normal stages of healing. They often take more than three months to resolve, and do not respond well to treatment ${ }^{[1,2]}$. Despite advances in diagnosis and treatment, chronic wounds still cause high morbidity today. The treatment and follow-up of these wounds is a difficult process for patients. Besides, they cause a serious financial burden on the healthcare system. It is reported that an average of 5.7 million patients receive treatment related to chronic wounds each year, with an estimated annual medical expenditure of $\$ 20$ billion in United States ${ }^{[1,2]}$.

The major causes of chronic wounds include diabetes, chronic compression, vascular pathologies, connective tissue diseases, and malignancies. Among these causes, the incidences of diabetes and diabetes-related complications continue to increase $^{[3]}$. Current data show that approximately $15 \%$ of the diabetic patient population has diabetic foot ulcers at some point in their lives ${ }^{[3,4]}$.

Diabetic foot infections are diagnosed using tissue cultures obtained from the lesion, vascular imaging, and bone and soft tissue imaging ${ }^{[5]}$. Although diabetes is one of the most common causes of chronic foot wounds, it may not be the cause of all foot wounds in people with diabetes. Especially in patients presenting with osteomyelitis, imaging findings such as an increase in deep soft tissue density and intramuscular radiolucent fascial plane deletion may also be observed in eosinophilic granulomas and tumors that cause inflammatory reactions in surrounding tissues ${ }^{[2,6]}$. Furthermore, findings of sequestrum in the bone in patients with chronic osteomyelitis should not always suggest osteomyelitis; noninfective pathologies such as eosinophilic granuloma, lymphoma, and fibrosarcoma should also be considered in the differential diagnosis ${ }^{[2,7]}$. In such cases, histopathological examination of tissue samples obtained from lesioned areas is important in terms of treatment and followup strategies. In the present case, the patient had received various antimicrobial treatments for her right foot wound over six months. However, the result of the histopathological examination of the tissue sample was consistent with Kaposi's sarcoma, after which the patient's treatment was aimed at treating her diagnosis of malignancy.

\section{Ethics}

Informed Consent: Consent form was filled out by the presented patient.

Peer-review: Externally and internally peer-reviewed.

\section{Authorship Contributions}

Surgical and Medical Practices: M.I.T., Ş.Ç., I.E.S., Concept: M.I.T., Design: I.E.S., Data Collection or Processing: Ş.Ç., Analysis or Interpretation: T.A., Literature Search: S.M., Writing: S.M.

Conflict of Interest: No conflict of interest was declared by the authors.

Financial Disclosure: The authors declared that this study received no financial support.

\section{References}

1. Branski LK, Gauglitz GG, Herndon DN, Jeschke MG. A review of gene and stem cell therapy in cutaneous wound healing. Burns. 2009;35:171-80.

2. Coskun O, Uzun G, Dal D, Yildiz S, Sonmez YA, Yurttas Y, Guler A, Mutluoglu M, Tekindur S, Sarı S, Sahin MA, Zor F, Tanyuksel M. Approaches to Chronic Wound Care. Gülhane Tıp Derg. 2016;58:207-28.

3. Işıkgöz Taşbakan M, Yıldırım Şimşir I, Mermer S, Uysal S, Öztürk M, Çetinkalp Ş. Intralesional epidermal growth factor therapy for diabetic foot ulcers: an evaluation of 15 cases. Turk J Med Sci. 2017;47:1500-4.

4. Muhtaroğlu S, Barlak Keti D, Ünlühizarci K. Investigation of ischemiamodified albumin levels and some atherosclerosis- related serum parameters in patients with diabetic foot. Turk J Med Sci. 2016;46:126-32.

5. Uysal S, Arda B, Tasbakan MI, Cetinkalp S, Simsir IY, Öztürk AM, Uysal A, Ertam I. Risk factors for amputation in patients with diabetic foot infection: a prospective study. Int Wound J. 2017;14:1219-24.

6. Pineda C, Espinosa R, Pena A. Radiographic imaging in osteomyelitis: the role of plain radiography, computed tomography, ultrasonography, magnetic resonance imaging, and scintigraphy. Semin Plast Surg. 2009;23:80-9.

7. Tuncel E. Diyagnostik Radyoloji. In: Tuncel E (ed). Bursa: Uludağ Üniversitesi Basımevi, 1983:710-3. 